\title{
Гетероструктуры InGaAlAs/InAlAs на фосфид индиевой подложке для электрооптического модулятора Маха-Цендера
}

\author{
Д.В. Гуляев, Д.В. Дмитриев, Е.А. Колосовский, А.В. Царев, К.С. Журавлев \\ Институт физики полупроводников им. А.В. Ржанова СО РАН, Новосибирск, \\ 630090, пр. Лаврентьева, 13 \\ тел:+7 (383) 330-4475, факс:+7 (383) 333-2771, эл.nочта: gulyaev@isp.nsc.ru
}

DOI 10.34077/RCSP2021-87

В данной статье мы приводим результаты работы по получению и изучению свойств гетероэпитаксиальных структур (ГЭС) InAlGaAs/InAlAs на подложке InP предназначенных для создания на их основе электрооптического модулятора на основе квантово-размерного эффекта Штарка. Особенностью предлагаемой конструкции модулятора является размещение слоя из нескольких InAlGaAs квантовых ям над толстым буферным слоем $\operatorname{In}_{0.52} \mathrm{Al}_{0.48} \mathrm{As}$ с показателем преломления, превышающим показатель преломления подложки InP. В этом случае слой множественных квантовых ям остается волноводным и в нем формируется основная оптическая мода с небольшим сечением. Оптическая мода во втором волноводе, сформированном из буферного слоя $\mathrm{In}_{0.52} \mathrm{Al}_{0.48} \mathrm{As}$, характеризуется гораздо большим поперечным сечением, что может обеспечить удобное соединение с оптическим волокном [1].

При выращивании гетероструктур методом молекулярно-лучевой эпитаксии были отработаны условия роста четырехкомпонентного твердого раствора InGaAlAs с кристаллической решеткой согласованной с (001) InP подложкой, и определены оптимальные условия роста для каждого слоя ГЭС. В результате были получены гетероструктуры с концентрацией дефектов на поверхности не более 500 на см ${ }^{2}$, что достаточно для создания на их основе интегрированных оптических модуляторов.

Для исследования величины электро-оптического эффекта изготовлены тестовые ріп образцы, содержащие множественные

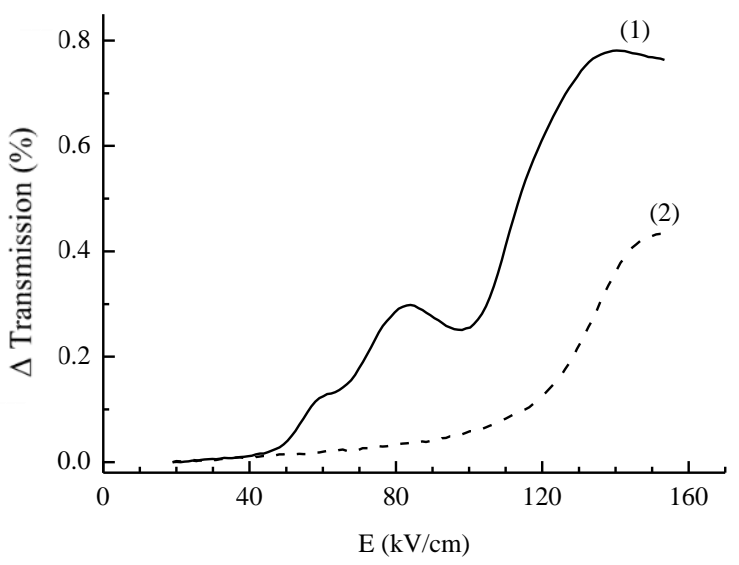

Рис. 1. Типичное относительное изменение к/та прохождения InGaAlAs/InAlAs МКЯ в электрическом поле. Толщина КЯ (1) 11 и (2) 15 нм.

InGaAlAs/InAlAs квантовые ямы различного состава и толщины слоев. Проведено измерение зависимостей коэффициента отражения/пропускания образцов от напряжения электрического поля на рабочей длине модулятора 1.55 мкм. Обнаружена немонотонная зависимость коэффициента отражения/прохождения от приложенного электрического поля, в кривых присутствуют ярко выраженные резонансы/пики (см. рис. 1). Из сравнения экспериментальных и расчетных зависимостей показателя преломления в электрическом поле показано, что этот эффект связан с появлением непрямых оптических переходов между уровнями соседних квантовых ям [2].

Методом эллипсометрии для всех слоев ГЭС, различающихся составом и уровнем легирования установлены вещественная и мнимая часть коэффициента преломления. Проведено сравнение полученных данных с данными моделирования и выбрана оптимальная конструкция структуры, характеризующаяся минимальными оптическими потерями при максимальном электрооптическом эффекте.

Исследование выполнено при финансовой поддержке РФФИ и Новосибирской области в рамках научного проекта 20-42-540009.

\section{Литература}

[1] А.В. Царев, Р.М. Тазиев, // Квант. электроника. 2019. т. 49, С.266.

[2] G. D. Boyd, D. A. B. Miller, D. S. Chemla, S. L. McCall, A. C. Gossard, and J. H. English // Appl. Phys. Lett., 1987. T.50, C.1119. 